\title{
Pengaruh Lingkungan Kerja, Disiplin, Motivasi Dan Kepuasan Kerja Terhadap Prestasi Kerja Karyawan Pt. Pegadaian (Persero) Kota Padang
}

\author{
Vivi Nila Sari \\ Universitas Putra Indonesia "YPTK" Padang \\ vivinilasari@upiyptk.ac.id
}

\begin{abstract}
This study aims to find out how much the influence of the Work Environment, Discipline, Motivation and Job Satisfaction on Employee Performance at PT. Pegadaian (Persero) Kota Padang. This study consisted of four independent variables, namely the Work Environment, Discipline, Motivation and Job Satisfaction and one Dependent variable namely Job Performance. The analytical method used is correlation and regression. The method of data collection in this study is to use a questionnaire filled out by respondents namely employees of PT. Pegadaian (Persero) Kota Padang. The results obtained based on the Partial Test ( $t$ test) were obtained: (a) there is a positive and significant influence between the Work Environment on Employee Performance, (b) There is a positive and significant influence between Discipline on Employee Performance,. (c) There is a positive and significant influence between Motivation on Employee Performance, and there is a positive and significant influence between Job Satisfaction and Achievement Employee work,
\end{abstract}

Keywords: Work Environment, Discipline, Motivation, Job Satisfaction, Work Achievement.

\section{Pendahuluan}

Salah satu masalah dalam ketenagakerjaan yang perlu mendapatkan perhatian yang lebih khusus yaitu prestasi kerja karyawan. Aspek ini menentukan sekali dalam usaha pencapaian suatu tingkat produktivitas yang cukup tinggi. Oleh karena itu, perusahaan harus mengelola Sumber Daya Manusia dengan sebaik mungkin guna untuk meningkatkan prestasi karyawan PT. Pegadaian (Persero) Kota Padang. Karena peran karyawan tidak hanya untuk menjadi karyawan biasa saja, melainkan diperlukan peran karyawan yang berprestasi. Sumber daya menusia merupaka tokoh sentral dalam organisasi agar aktivitas berjalan dengan baik oleh sebab itu PT. Pegadaian (Persero) Kota Padang harus memiliki karyawan yang berpengetahuan tinggi. Prestasi kerja yang bagus adalah Prestasi yang optimal.

Disiplin harus ditanamkan dalam diri masing-masing karyawan suatu perusahaan, maka dari itu perlu ditetapkan peraturan secara tertulis dan setiap yang melanggar harus dikenakanan sanksi dari setiap pelanggaran yang dilakukan.

\section{Tabel 1}

Kedisiplinan Karyawan PT.Pegadaian (Persero) Kota Padang

\begin{tabular}{|l|llcc|}
\hline No & Faktor Penyebab Rendah & \multicolumn{3}{c|}{ Persentase } \\
\cline { 3 - 5 } & Disiplin Kerja Karyawan & 2015 & 2016 & 2017 \\
\hline 1 & $\begin{array}{l}\text { Terkait sikap: kurangnya } \\
\text { kesadaran karyawan dalam } \\
\text { datang tepat waktu }\end{array}$ & $57 \%$ & $56 \%$ & $50 \%$ \\
\hline
\end{tabular}




\begin{tabular}{|c|c|c|c|}
\hline 2 & $\begin{array}{l}\text { Terkait tingkah laku: } \\
\text { karyawan yang masih lalai } \\
\text { dalam menjalankan tugas. }\end{array}$ & $29 \%$ & $22 \%$ \\
\hline 3 & $\begin{array}{lr}\text { Terkait } & \text { peraturan: } \\
\text { karyawan } & \text { sering } \\
\text { melanggar aturan } & \end{array}$ & & \\
\hline 4 & Total & $100 \%$ & $100 \%$ \\
\hline
\end{tabular}

Sumber: Hasil Survei dari Deputi PT. Pegadaian (Persero) Kota Padang Tahun 2017

Berdasarakan tabel 1 masalah disiplin di PT. Pegadaian (Persero) Kota Padang masih rendah, ini dapat dilihat dari masih ada nya karyawan yang datang terlambat walaupun sudah di tetapkan sistem absen menggunakan fingerprint. Dalam terkait sikap terdapat 57\% pada tahun 2015, 56\% untuk tahun 2016 dan 50\% untuk tahun 2017 mengenai kurangnya kesadaran karyawan dalam datang tepat waktu. Terkait tingkah laku dimana terdapat 29\% untuk tahun 2015, 22\% untuk tahun 2016 dan $28 \%$ untuk tahun 2017 mengenai karyawan yang masih lalai dalam menjalankan tugas. Kemudian terkait peraturan terdapat $14 \%$ untuk tahun $2015,22 \%$ untuk tahun 2016 dan $12 \%$ untuk tahun 2017 mengenai karyawan yang sering melanggar aturan.

Lingkungan kerja merupakan salah satu wadah bagi karyawan untuk ketenangan bekerja. Sehingga secara langsung maupun tidak langsung lingkungan kerja mempengaruhi dalam kerjanya. Permasalahan lingkungan kerja yang ada dalam perusahaan ini yaitu kurangnya fasilitas dibagian unit pelayanan cabang (UPC). Jadi disini peneliti ingin meneliti apakah di unit perusahaan ini sudah mampu memfasilitaskan karyawan dengan cukup.

Motivasi merupakan alat pendorong karyawan untuk bekerja dengan sebaikbaiknya. Dengan motivasi karyawan dapat meningkatkan kualitas kerja pada karyawan itu untuk mencapai prestasi yang diinginkan. Permasalahnya motivasi pada perusahaan ini yaitu banyaknya produk yang dipegang oleh karyawan hingga karyawan menjadi terdemotivasi.

Kepuasan kerja juga berpengaruh kepada setiap karyawan yang ada dalam perusahaan, sikap emosional yang menyenangkan dan mencintai pekerjaannya. Kepuasan kerja dapat diketahui dari kesediaan karyawan dalam menjalani tugasnya. Permasalahan kepuasan dalam perusahaan ini yaitu tingginya keluar masuk nya karyawan yang ada di perusahaan.

\section{Tinjauan Pustaka}

\section{Lingkungan Kerja}

Menurut [1] Lingkungan kerja merupakan salah satu faktor penting dalam menciptakan prestasi kerja karyawan. Karena lingkungan kerja mempunyai pengaruh langsung terhadap karyawan didalam menyelesaikan pekerjaan yang pada akhirnya akan meningkatkan prestasi organisasi. Suatu kondisi lingkungan kerja dikatakan baik apabila karyawan dapat melaksanakan kegiatan secara optimal, sehat, aman, dan nyaman. Oleh karena itu penentuan dan penciptaan lingkungan kerja yang baik akan sangat menentukan keberhasilan pencapaian tujuan organisasi. Sebaliknya apabila lingkungan kerja yang tidak baik akan dapat menurunkan motivasi serta semangat kerja dan akhirnya dapat menurunkan kinerja karyawan. Lingkungan kerja sangatlah perlu untuk diperhatikan karena merupakan salah satu faktor yang penting dalam menentukan prestasi karyawan. Hal ini dikarenakan mereka merasa tidak nyaman dalam bekerja sehingga prestasi 
menjadi rendah. Lingkungan kerja adalah sesuatu dari lingkungan pekerjaan yang memudahkan atau menyulitkan pekerjaan. Terdapat dua jenis lingkungan kerja yaitu lingkungan kerja fisik dan lingkungan kerja non fisik.

\section{Disiplin}

Menurut [2] disiplin kerja adalah kegiatan manajemen untuk menjalankan standar-standar organisasional.

\section{Motivasi}

Menurut [3] bahwa motivasi merupakan proses psikologis yang membangkitkan dan mengarahakan prilaku pada pencapain tujuan atau gold directed behavior. Manajer perlu memahami proses psikologi ini apabila mereka ingin berhasil membina pekerjaan menuju pada penyelesaian sasaran organisasi. [3] berpendapat bahwa motivasi merupakan serangkaian proses yang membangkitkan (arouse), mengarahkan (direct), dan menjaga (maintain) prilaku manusia menunju pada pencapaian tujuan.

\section{Kepuasan Kerja}

Kepuasan kerja adalah sikap umum terhadap pekerjaan seseorang, yang menunjukkan perbedaan antara jumlah penghargaan yang mereka diterima pekerja dan jumlah yang mereka yakini seharusnya mereka terima [3]. Kepuasan kerja merupakan suatu cara pandang seseorang baik yang bersifat positif maupun bersifat negative tentang pekerjaannya [4]

\section{Prestasi Kerja}

Menurut [5] Prestasi Kerja adalah hasil kerja yang dicapai seseorang dalam melaksanakan tugas-tugas yang dibebankan kepadanya, yang didasarkan atas kecakapan, pengalaman dan kesungguhan serta waktu.

\section{Hubungan Lingkungan Kerja dengan Prestasi Kerja}

Penelitian yang dilakukan oleh [6] yang berjudul "Pengaruh Pelatihan Kerja dan Lingkungan Kerja Terhadap Prestasi Kerja Karyawan PT. Jamsostek (Persero) Kantor Cabang Malang”. Berdasarkan penelitiannya variabel lingkungan kerja berpengaruh signifikan terhadap prestasi kerja karyawan. Hal tersebut dikarnakan lingkungan kerja ada kaitannya dengan prestasi kerja. Lingkungan kerja yang menjadi pedoman memberikan kenyamanan kepada karyawan ataupun pekerjannya.

\section{Hubungan Disiplin Kerja dengan Prestasi Kerja}

Dalam penelitian yang diteliti oleh [7] yang berjudul "Pengaruh Pelatihan, Kompensasi, dan Disiplin Kerja Terhadap Prestasi Kerja Karyawan PT. PLN (Persero) Area Pelayanan Dan Jaringan Malang". Berdasarkan penelitiannya variabel disiplin kerja berpengaruh positif terhadap prestasi kerja. Hal ini disebabkan disiplin kerja akan membantu prestasi kerja pada karyawan. Jadi, setiap karyawan harus menjaga kedisiplinannya sehingga ia bisa meningkatkan prestasi kerja.

\section{Hubungan Motivasi Kerja dengan Prestasi Kerja}

Penelitian yang diteliti oleh [8] yang berjudul "Pengaruh Motivasi Kerja dan Disiplin Kerja Terhadap Prestasi Kerja Karyawan PT. Asuransi Jiwasraya Branch Office Malang". Menunjukkan bahwa motivasi kerja berpengaruh positif pula terhadap prestasi 
kerja. Dengan adanya motivasi karyawan menjadi semakin bersemangat dalam menjalankan pekerjaannya, otomatis prestasi kerja karyawan bisa saja meningkat. Oleh karena itu, meningkatkan motivasi kerja sangat penting dalam perusahaan agar timbul semangat kerja pada karyawan.

\section{Hubungan Kepuasan Kerja dengan Prestasi Kerja}

Penelitian yang dilakukan oleh [9] yang berjudul "Pengaruh Kepuasan Kerja dan Semangat Kerja Terhadap Prestasi Kerja Pada PT. Bumi Karsa Makassar". Berdasarkan penelitian tersebut, kepuasan kerja berpengaruh positif terhadap prestasi kerja. Hal ini sebabkan karena adanya kaitan antara kepuasan kerja dengan prestasi kerja. Hasil penelitian menunjukkan bahwa perubahan yang terjadi pada tingkat kepuasan kerja menyebabkan penurunan prestasi kerja karyawan.

\section{Kerangka Pemikiran}

Berdasarkan landasan teori dan rumusan masalah penelitian mengidentifikasi bahwa variable independen (X) yaitu Lingkungan Kerja, Disiplin, Motivasi Kerja dan Kepuasan Kerja dan variable dependen (Y) yaitu Prestasi Kerja, dapat digambarkan sebagai berikut :

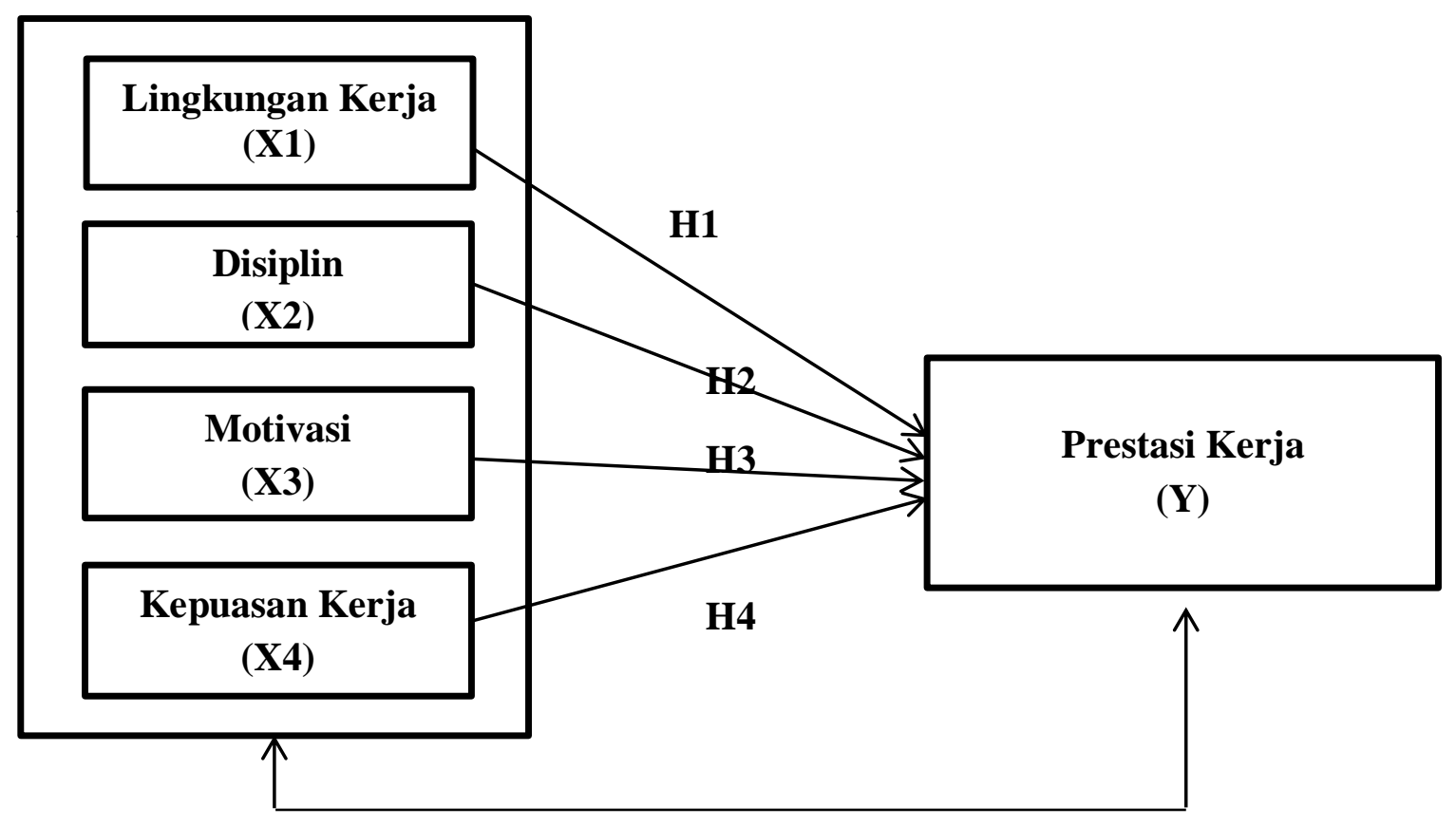

Gambar 1

\section{Kerangka Pemikiran}

\section{Hipotesis}

H1 : Lingkungan Kerja Berpengaruh terhadap Prestasi Kerja Karyawan PT. Pegadaian (Persero) Kota Padang.

H2 : Disiplin Berpengaruh terhadap Prestasi Kerja Karyawan PT. Pegadaian (Persero) Kota Padang.

H3 : Motivasi Berpengaruh terhadap Prestasi Kerja Karyawan PT. Pegadaian (Persero) Kota Padang. 
H4 : Kepuasan Kerja Berpengaruh terhadap Prestasi Kerja Karyawan PT. Pegadaian (Persero) Kota Padang.

\section{Metode Penelitian}

\section{Rancangan Kegiatan}

Berdasarkan tujuan penelitian yang telah ditetapkan dengan adanya hipotesis yang hendak diuji, maka jenis penelitian ini adalah penelitian penjelasan (explanatory research).Penelitian ini menggunakan seluruh sampel yang berjumlah 76 orang. Metode pengumpulan data dalam penelitian ini melalui penyebaran kuesioner kepada seluruh karyawan PT. Pegadaian (Persero) Kota Padang sebanyak 76 orang dan pencatatan dokumentasi yang dapat menunjang penelitian.

\section{Ruang Lingkup Atau Objek}

Adapun ruang lingkup atau objek yang di teliti peneliti yaitu pada perusahaan yang telah ditentukan sebelumnya yaitu pada PT. Pegadaian (Persero) Kota Padang.

\section{Teknik Pengumpulan Data}

Teknik Pengumpulan data penelitian ini dilakukan dengan cara penyebaran kuesioner kepada responden dengan panduan kuesioner yang berisi pertanyaan berdasarkan indikator yang diajukan. Penelitian ini bersifat kuantitatif.

\section{Definisi Operasional Variabel}

\section{Prestasi Kerja (Y)}

Prestasi kerja dapat diartikan sebagai hasil yang dicapai seseorang menurut ukuran yang berlaku untuk pekerjaan yang bersangkutan. Prestasi kerja adalah hasil kerja yang dicapai seseorang dalam melaksanakan tugas-tugas yang dibebankan kepadanya yang didasarkan dengan kemampuan yang lebih diambil dari kecakapan, pengalaman dan kesungguhan serta waktu.

\section{Lingkungan Kerja (X1)}

Lingkungan kerja adalah sesuatu yang ada disekitar para pekerja dan yang mempengaruhi dirinya dalam menjalankan tugas-tugas yang dibebankan kepadanya. Demikian pula halnya ketika melakukan pekerjaan, karyawan sebagai manusia tidak dapat dipisahkan dari berbagai keadaan disekitar tempat mereka bekerja, yaitu lingkungan kerja.

\section{Disiplin Kerja (X2)}

Disiplin adalah suatu kekuatan yang berkembang di dalam tubuh karyawan dan menyebabkan karyawan dapat menyesuaikan diri dengan sukarela pada keputusan peraturan, dan nilai-nilai tinggi dari pekerjaan dan perilaku. Disiplin dalam arti sempit dihubungkan dengan hukuman. Tindakan menghukum seorang karyawan ini sebenarnya hanya merupakan sebagian dari persoalan disiplin, tindakan ini dilakukan saat usaha-usaha pendekatan secara konstruktif mengalami kegagalan.

\section{Motivasi Kerja (X3)}

Motivasi kerja adalah suatu alasan yang mendorong karyawan untuk bekerja di sebuah perusahaan. Dan motivasi kerja juga dorongan karyawan untuk mengerjakan beban 
kerjanya agar pekerjaannya bisa terselesaikan dengan hasil sesuai dengan yang diinginkan. Definisi motivasi sebagai hasil sejumlah proses yang bersifat internal atau eksternal bagi seorang individu, yang menyebabkan timbulnya sikap antusiasme dalam melaksanakan kegiatan-kegiatan tertentu.

\section{Kepuasan Kerja (X4)}

Kepuasan kerja adalah sikap dan keadaan emosional yang menyenangkan yang dirasakan karyawan terhadap pekerjaannya yang dapat dipengaruhi dari berbagai aspek-aspek antara lain pekerjaan itu sendiri, promosi, gaji, rekan kerja dan supervise

\section{Teknik Analisis}

Analisis data yang digunakan sebagai berikut:

1. Analisis Deskriptif Menurut [10] statistik deskriptif adalah "statistik yang digunakan untuk menganalisis data dengan cara mendeskripsikan atau menggambarkan data yang telah berkumpul sebagaimana adanya tanpa bermaksud membuat kesimpulan yang berlaku untuk umum atau generalisasi

2. Pengujian Hipotesis

a) Uji t (parsial) Uji t dilakukan untuk menguji signifikasi masing-masing variabel bebas secara parsial atau untuk mengetahui variabel bebas mana yang lebih berpengaruh diantara kedua variabel $(\mathrm{X})$ terhadap variabel terikat (Y).

b) Uji F (Simultan) Perhitungan uji $\mathrm{F}$ berdasarkan pada hitungan komputer program SPSS windows. [10] menyatakan bahwa uji $F$ digunakan untuk menguji secara simultan apakah adanya pengaruh antara variabel Lingkungan Kerja (X1) Disiplin Kerja (X2), Motivasi Kerja (X3) dan Kepuasan Kerja (X4) dengan Prestasi kerja karyawan (Y) itu signifikan atau tidak

\section{Hasil dan Pembahasan}

\section{Analisis Regresi Linear Berganda}

Analisis regresi linier berganda bertujuan untuk menengetahui seberapa besar pengaruh variabel bebas terhadap variabel terikat. Berdasarkan hasil analisis regresi yang dilakukan peneliti, maka diperoleh pengaruh Lingkungan Kerja, Disiplin Kerja, Motivasi Kerja dan Kepuasan Kerja terhadap Prestasi Kerja seperti yang terlihat pada tabel berikut ini:

Tabel 2. Analisis Regresi Linier Berganda Lingkungan Kerja, Disiplin Kerja, Motivasi Kerja dan Kepuasan Kerja terhadap Prestasi Kerja

Coefficients $^{\mathbf{a}}$

\begin{tabular}{|lccccccc|}
\hline Model & \multicolumn{2}{c}{$\begin{array}{c}\text { Unstandardized } \\
\text { Coefficients }\end{array}$} & $\begin{array}{c}\text { Standardized } \\
\text { Coefficients }\end{array}$ & t & Sig. & R \\
& B & Std. Error & Beta & & & R & Square \\
(Constant) & 5.638 & 1.631 & & 3.457 & 0,001 & & \\
Lingkungan Kerja & 0,454 & 0,140 & 0,335 & 3.236 & 0,002 & & \\
Disiplin Kerja & 0,449 & 0,170 & 0,246 & 2.634 & 0,010 & 0,947 a & 0,892 \\
Motivasi Kerja & 0,143 & 0,060 & 0,157 & 2.373 & 0,020 & & \\
Kepuasan Kerja & 0,300 & 0,143 & 0,266 & 2.093 & 0,040 & & \\
\hline
\end{tabular}

Sumber : Hasil Pengolahan SPSS versi 21. 
Pada tabel 2 dapat dilihat bahwa nilai konstanta (a) sebesar 5.638 sedangkan koefisien regresi Lingkungan Kerja (X1) sebesar 0.454, Disiplin Kerja (X2) sebesar 0.449, Motivasi Kerja (X3) sebesar 0,143, dan Kepuasan kerja (X4) sebesar 0,300 dari nilai ini dapat diformulasikan dalam bentuk persamaan regresi dibawah ini:

Formula : $\mathrm{Y}=\mathrm{a}+\mathrm{b} 1 \mathrm{X} 1+\mathrm{b} 2 \mathrm{X} 2+\mathrm{b} 3 \mathrm{X} 3+\mathrm{b} 4 \mathrm{X} 4$

Sehingga diperoleh persamaan regresi untuk pengaruh variabel Lingkungan Kerja, Disiplin Kerja, Motivasi Kerja dan Kepuasan Kerja terhadap Prestasi Kerja sebagai berikut:

$$
\mathrm{Y}=5.638+0,4543 \mathrm{X} 1+0,449 \mathrm{X} 2+0,143 \mathrm{X} 3+0,300 \mathrm{X} 4
$$

Interpretasi berdasarkan persamaan tersebut dapat diartikan sebagai berikut:

a. Constanta sebesar 5.638, apabila Lingkungan Kerja, Disiplin Kerja, Motivasi Kerja dan Kepuasan Kerja tidak ada maka Prestasi Kerja tetap sebesar konstanta yaitu 5.638 .

b. Lingkungan Kerja sebesar 0.454 , apabila terjadi peningkatan Lingkungan Kerja. Sebesar 1 satuan dengan asumsi Disiplin Kerja, Motivasi Kerja dan Kepuasan Kerja diabaikan akan mengakibatkan kenaikan Prestasi Kerja sebesar 0.454 satuan. Tanda positif pada koefisien X1 menunjukkan bahwa Lingkungan Kerja mempunyai pengaruh yang searah terhadap Prestasi Kerja.

c. Disiplin Kerja sebesar 0.449, apabila terjadi peningkatan Disiplin Kerja sebesar 1 satuan dengan asumsi Lingkungan Kerja, Motivasi Kerja dan Kepuasan Kerja diabaikan akan mengakibatkan kenaikan Prestasi Kerja sebesar 0.449 satuan. Tanda positif pada koefisien X2 menunjukkan bahwa Disiplin Kerja mempunyai pengaruh yang searah terhadap Prestasi Kerja.

d. Motivasi Kerja sebesar 0.143, apabila terjadi peningkatan Motivasi Kerja sebesar 1 satuan dengan asumsi Lingkungan Kerja, Disiplin Kerja dan Kepuasan Kerja diabaikan akan mengakibatkan kenaikan Prestasi Kerja sebesar 0.143 satuan. Tanda positif pada koefisien X3 menunjukkan bahwa Motivasi Kerja mempunyai pengaruh yang searah terhadap Prestasi Kerja.

e. Kepuasan Kerja sebesar 0,300, apabila terjadi peningkatan Kepuasan Kerja sebesar 1 satuan dengan asumsi Lingkungan Kerja, Disiplin Kerja dan Motivasi Kerja diabaikan akan mengakibatkan kenaikan Prestasi Kerja sebesar 0,300 satuan. Tanda negatif pada koefisien X4 menunjukkan bahwa Kepuasan Kerja mempunyai pengaruh yang searah terhadap Prestasi Kerja.

f. Nilai $\mathrm{R}^{2}$ atau $\mathrm{R}$ square adalah sebesar 0.892 besarnya nilai tersebut memberikan implikasi bahwa pengaruh variabel bebas (Lingkungan Kerja, Disiplin Kerja, Motivasi Kerja, Kepuasan Kerja) adalah sebesai 89,2\% sedangkan sisanya $10,8 \%$ mungkin dipengaruhi oleh variabel-variabel lain diluar penelitian ini.

\section{Uji Hipotesis}

\section{Pengujian Hipotesis Secara Persial (Uji t)}

Uji t dimaksud untuk menguji signifikan pengaruh variabel bebas dan variabel terikat secara parsial. Dimana pengujian ini membandingkan antara probabilitas signifikan dengan alpha 0,05 . Dari hasil pengujian ini bila probabilitas signifikan lebih kecil dari pada alpha 0,05 maka diperoleh $\mathrm{H}_{\mathrm{o}}$ ditolak dan $\mathrm{H}_{\mathrm{a}}$ diterima, berarti ada hubungan dan bila probabilitas signifikan lebih besar dari pada alpha 0,05 maka $\mathrm{H}_{\mathrm{o}}$ diterima dan $\mathrm{H}_{\mathrm{a}}$ ditolak, berarti tidak ada hubungan. Derajat kebebasan (df) n-k-1 yaitu 76-4-1=71 ( $\mathrm{n}$ adalah jumlah kasus / responden dan $\mathrm{k}$ adalah jumlah variabel independen) 
sehingga hasil yang diperoleh untuk t tabel sebesar 1,9939. Dari hasil olah data dapat disajikan pada tabel berikut:

Tabel 3

Pengujian Hipotesis Secara Parsial (Uji T)

\begin{tabular}{|ccccl|}
\hline $\begin{array}{c}\text { Faktor } \\
\text { Independen }\end{array}$ & $\begin{array}{c}\mathbf{t} \\
\text { hitung }\end{array}$ & t table & Signifikan & $\begin{array}{l}\text { Perlakuan } \\
\text { Terhadap } \\
\text { Hipotesis }\end{array}$ \\
\hline $\begin{array}{c}\text { Lingkungan Kerja } \\
\text { (X1) }\end{array}$ & 3,236 & 1.9939 & 0.002 & $\begin{array}{l}\mathrm{H}_{\mathrm{o}} \text { ditolak } \\
\mathrm{H}_{\mathrm{a}} \text { diterima }\end{array}$ \\
\hline $\begin{array}{c}\text { Disiplin Kerja } \\
\text { (X2) }\end{array}$ & 2.634 & 1.9939 & 0.010 & $\begin{array}{l}\mathrm{H}_{\mathrm{o}} \text { ditolak } \\
\mathrm{H}_{\mathrm{a}} \text { diterima }\end{array}$ \\
\hline $\begin{array}{c}\text { Motivasi Kerja } \\
\text { (X3) }\end{array}$ & 2,373 & 1.9939 & 0.020 & $\begin{array}{l}\mathrm{H}_{\mathrm{o}} \text { ditolak } \\
\mathrm{H}_{\mathrm{a}} \text { diterima }\end{array}$ \\
\hline $\begin{array}{c}\text { Kepuasan Kerja } \\
\text { (X4) }\end{array}$ & 2,093 & 1.9939 & 0.040 & $\begin{array}{l}\mathrm{H}_{\mathrm{o}} \text { ditolak } \\
\mathrm{H}_{\mathrm{a}} \text { diterima }\end{array}$ \\
\hline
\end{tabular}

Sumber: Hasil Pengolahan SPSS 21

Berdasarakan tabel 3 dapat diinterperstasikan sebagai berikut:

1. Pengaruh Lingkungan kerja (X1) terhadap Prestasi Kerja (Y)

Dari tabel 3 terlihat thitung 3,236 dan tabel 1.9939 dimana thitung lebih besar dari t tabel $3,236<0,1.9939)$ atau tingkat signifikan lebih kecil dari alpha $(0,68>0,05)$ maka $\mathrm{H}_{\mathrm{o}}$ ditolak dan $\mathrm{H}_{\mathrm{a}}$ diterima

Dimana :

a. $\mathrm{H}_{\mathrm{o}}$ : Secara parsial tidak ada pengaruh signifikan antara Lingkungan Kerja terhadap Prestasi Kerja

b. $\mathrm{H}_{\mathrm{a}}$ : Secara parsial ada pengaruh signifikan antara Lingkungan Kerja terhadap Prestasi Kerja.

2. Pengaruh Disiplin kerja (X2) terhadap Prestasi Kerja (Y)

Dari tabel 3 terlihat thitung 2.634 dan tabel 1.9939 dimana thitung lebih besar dari tabel $(2.634>1.9939)$ atau tingkat signifikan lebih kecil dari alpha $(0,00<0,05)$ maka $\mathrm{H}_{\mathrm{o}}$ ditolak dan $\mathrm{H}_{\mathrm{a}}$ diterima.

Dimana :

a. $\mathrm{H}_{\mathrm{o}}$ : Secara parsial tidak ada pengaruh signifikan antara Disiplin Kerja terhadap Prestasi Kerja

b. $\mathrm{H}_{\mathrm{a}}$ : Secara parsial ada pengaruh signifikan antara Disiplin Kerja terhadap terhadap Prestasi Kerja.

3. Pengaruh Motivasi Kerja kerja (X3) terhadap Prestasi Kerja (Y)

Dari tabel 3 terlihat thitung 2,373 dan tabel 1.9939 dimana thitung lebih besar dari tabel $(2,373<1.9939)$ atau tingkat signifikan lebih kecil dari alpha $(0,37>0,05)$ maka $\mathrm{H}_{\mathrm{o}}$ ditolak dan $\mathrm{H}_{\mathrm{a}}$ diterima.

Dimana :

c. $\mathrm{H}_{\mathrm{o}}$ : Secara parsial tidak ada pengaruh signifikan antara Motivasi Kerja terhadap Prestasi Kerja

d. $\mathrm{H}_{\mathrm{a}} \quad$ : Secara parsial ada pengaruh signifikan antara Motivasi Kerja terhadap Prestasi Kerja. 
4. Pengaruh Kepuasan kerja (X4) terhadap Prestasi Kerja (Y)

Dari tabel 3 terlihat thitung 2,093 dan tabel 1.9939 dimana thitung lebih besar dari tabel $(2,093<1.9939)$ atau tingkat signifikan lebih kecil dari alpha $(0,24>0,05)$ maka $\mathrm{H}_{\mathrm{o}}$ ditolak dan $\mathrm{H}_{\mathrm{a}}$ diterima.

Dimana :

e. $\mathrm{H}_{\mathrm{o}} \quad$ : Secara parsial tidak ada pengaruh signifikan antara Kepuasan Kerja terhadap Prestasi Kerja

f. $\mathrm{H}_{\mathrm{a}}$ : Secara parsial ada pengaruh signifikan antara Kepuasan Kerja terhadap Prestasi Kerja.

Berdasarakan hasil perbandingan terlihat $\mathrm{t}$ hitung dan $\mathrm{t}$ tabel maka dapat diambil kesimpulan bahwa sacara parsial ada pengaruh yang signifikan antara Disiplin terhadap Prestasi Kerja.

\section{Pengujian Hipotesis Secara Bersama-Sama/Serempak (Uji F)}

Uji koefisien regresi secara bersama-sama dilakukan dengan Uji F (ANOVA). Uji ini digunakan untuk mengetahui apakah variabel independen secara bersama-sama berpengaruh terhadap variabel dependen. Signifikan berarti hubungan yang terjadi dapat berlaku untuk populasi (dapat digeneralisasikan). Pengujian dilakukan dengan uji $\mathrm{F}$ (ANOVA). Uji F menggunakan taraf signifikan 0,05 (uji 2 sisi) df 3 (n-k-1) atau 76-4-1 = 71, maka hasil yang diperoleh untuk Ftabel sebesar 2,50. Uji F dimaksud untuk menguji hipotesa dari penelitian yang menyatakan bahwa variabel Lingkungan Kerja (X1), Disiplin Kerja (X2), Motivasi Kerja (X3) dan Kepuasan Kerja (X4) mempunyai pengaruh signifikan terhadap Prestasi Kerja (Y). Hasil pengujian hipotesis secara simultan dapat dilihat pada tabel dibawah ini:

\begin{tabular}{|c|c|c|c|c|c|c|}
\hline & & ıjian Hipote & $\begin{array}{l}\text { Tabe } \\
\text { ecara } \\
\text { OVA }\end{array}$ & multan (Uj & & \\
\hline Model & & $\begin{array}{l}\text { Sum of } \\
\text { Squares }\end{array}$ & df & $\begin{array}{c}\text { Mean } \\
\text { Square }\end{array}$ & $\mathbf{F}$ & Sig. \\
\hline & Regression & 730.571 & 4 & 753.779 & 155.444 & $.000^{\mathrm{b}}$ \\
\hline 1 & Residual & 2245.469 & 71 & 4.849 & & \\
\hline & Total & 2976.039 & 75 & & & \\
\hline
\end{tabular}

Sumber: Hasil Pengolahan SPSS 21

Tabel 4 diatas menunjukkan pengujian yang dilakukan dengan cara membandingkan nilai Fhitung dengan Ftabel karena nilai Fhitung lebih besar dari nilai Ftabel (155.444 > 2,50). Maka diperoleh $\mathrm{H}_{\mathrm{o}}$ ditolak dan $\mathrm{H}_{\mathrm{a}}$ diterima, yang berarti hal ini dilakukan secara serempak antara Lingkungan Kerja, Disiplin Kerja, Motivasi Kerja dan Kepuasan Kerja berpengaruh signifikan terhadap Prestasi Kerja.

Tabel 5

Hasil Pengujian Hipotesis Penelitian

Hipotesis Pernyataan

Keputusan

\begin{tabular}{|lllll|}
\hline H1 & Terdapat pengaruh yang signifikan antara & Diterima \\
& $\begin{array}{l}\text { Lingkungan Kerja terhadap Prestasi Kerja } \\
\text { karyawan pada PT. Pegadaian (Persero) }\end{array}$ & \\
\hline $\mathrm{H}_{2}$ & Terdapat pengaruh yang signifikan antara & Diterima \\
\hline
\end{tabular}




\begin{tabular}{|c|c|c|c|}
\hline & $\begin{array}{l}\text { Disiplin Kerja terhadap Prestasi } \\
\text { karyawan pada PT. Pegadaian (Persero) }\end{array}$ & Kerja & \\
\hline $\mathrm{H}_{3}$ & $\begin{array}{l}\text { Terdapat pengaruh yang signifikan } \\
\text { Motivasi Kerja terhadap Prestasi } \\
\text { karyawan pada PT. Pegadaian (Persero) }\end{array}$ & $\begin{array}{r}\text { antara } \\
\text { Kerja }\end{array}$ & Diterima \\
\hline $\mathrm{H} 4$ & $\begin{array}{l}\text { Terdapat pengaruh yang signifikan } \\
\text { Kepuasan Kerja terhadap Prestasi } \\
\text { karyawan pada PT. Pegadaian (Persero) }\end{array}$ & $\begin{array}{r}\text { antara } \\
\text { Kerja }\end{array}$ & Diterima \\
\hline
\end{tabular}

Sumber: Data diolan sendiri

Analisis Determinasi (Uji R²)

\begin{tabular}{|c|c|c|c|c|}
\hline \multicolumn{5}{|c|}{$\begin{array}{c}\text { Tabel } 6 \\
\text { Hasil Analisis Determinasi } \\
\text { Model Summary }^{\mathrm{b}}\end{array}$} \\
\hline Model & $\mathrm{R}$ & R Square & $\begin{array}{l}\text { Adjusted R } \\
\text { Square }\end{array}$ & $\begin{array}{l}\text { Std. Error of } \\
\text { the Estimate }\end{array}$ \\
\hline 1 & $.947^{\mathrm{a}}$ & .898 & .892 & 2.20209 \\
\hline
\end{tabular}

Sumber: Hasil Pengolahan SPSS 21

Berdasarkan tabel 6 diperoleh angka $\mathrm{R}^{2}$ (R Square) sebesar 0,892 atau 89,2\%. Hal ini menunjukkan bahwa persentase sumbangan pengaruh lingkungan kerja, disiplin kerja, motivasi kerja dan kepuasan kerja terhadap prestasi kerja karyawan sebesar 89,2\%. Sedangkan sisanya sebesar $10,8 \%$ dipengaruhi atau dijelaskan oleh variabel-variabel lain di luar penelitian ini.

\section{Implikasi Hasil Penelitian}

Dari hasil penelitian tersebut dapat diimplikasikan hal-hal sebagai berikut.

1. Pengaruh Lingkungan Kerja (X1) dengan Prestasi Kerja (Y)

Terdapat pengaruh positif dan signifikan yang dapat dilihat dari t hitung 3,236 dan $\mathrm{t}$ tabel 1,9939 dimana t hitung lebih besar dari t tabel $(3,236>1,9939)$ dan tingkat signifikan lebih kecil dari alpha $(0,00<0,05)$. Dapat disimpulkan Lingkungan Kerja berpengaruh signifikan terhadap Prestasi Kerja Karyawan. Penelitian ini sejalan dengan penelitian yang dilakukan oleh [6] bahwa Lingkungan Kerja berpengaruh signifikan terhadap Lingkungan Kerja. Dengan demikian semakin nyaman dan kondusif lingkungan kerja, maka kinerja yang dijalankan semakin meningkat sehingga prestasi pun dapat meningkat.

2. Pengaruh Disiplin Kerja (X2) dengan Prestasi Kerja (Y)

Terdapat pengaruh positif dan signifikan yang dapat dilihat dari t hitung 2,634 dan t tabel 1,9939 dimana t hitung lebih besar dari t tabel $(2,634>1,9939)$ dan tingkat signifikan lebih kecil dari alpha $(0,01<0,05)$. Dapat disimpulkan Disiplin Kerja berpengaruh signifikan terhadap Prestasi Kerja Karyawan. Penelitian ini sejalan dengan penelitian [11] bahwa Disiplin Kerja berpengaruh signifikan secara simultan terhadap Prestasi Kerja. Dengan demikian, disiplin yang tinggi dapat meningkatkan prestasi kerja pada karyawan.

3. Pengaruh Motivasi Kerja (X3) dengan Prestasi Kerja (Y)

Terdapat pengaruh positif dan signifikan yang dapat dilihat dari t hitung 2,373 dan $\mathrm{t}$ tabel 1,9939 dimana $t$ hitung lebih besar dari $t$ tabel $(2,373>1,9939)$ dan tingkat signifikan lebih kecil dari alpha $(0,02<0,05)$. Dapat disimpulkan Motivasi Kerja 
berpengaruh signifikan terhadap Prestasi Kerja Karyawan. Penelitian ini sejalan dengan penelitian yang dilakukan oleh [12] dimana Motivasi Kerja berpengaruh signifikan terhadap Prestasi Kerja. Dengan demikian, adanya motivasi yang tinggi dapat meningkatkan semangat kerja karyawan sehingga prestasi karyawan dapat meningkat.

4. Pengaruh Kepuasan Kerja (X4) dengan Prestasi Kerja (Y)

Terdapat pengaruh positif dan signifikan yang dapat dilihat dari t hitung 2,093 dan $\mathrm{t}$ tabel 1,9939 dimana $t$ hitung lebih besar dari t tabel $(2,093>1,9939)$ dan tingkat signifikan lebih kecil dari alpha $(0,04<0,05)$. Dapat disimpulkan Kepuasan Kerja berpengaruh signifikan terhadap Prestasi Kerja Karyawan. Penelitian ini sejalan dengan penelitian yang dilakukan olah [9] dimana Kepuasan Kerja berpengaruh positif terhadap Prestasi Kerja pada karyawan. Dengan kepuasan yang didapat karyawan dapat meningkatkan prestasi kerja pada karyawan.

\section{Kesimpulan}

Berdasarkan hasil penelitian dan pembahasan tentang pengaruh Lingkungan Kerja, Disiplin Kerja, Motivasi Kerja dan Kepuasan Kerja terhadap Prestasi Kerja, maka peneliti dapat menarik kesimpulan sebagai berikut.

1. Dari hasil perbandingan terlihat thitung dan t tabel maka dapat diambil kesimpulan bahwa secara parsial ada pengaruh positif dan signifikan antara lingkungan kerja terhadap Prestasi Kerja. Dengan demikian Ho ditolak dan H2 diterima.

2. Dari hasil perbandingan terlihat $t$ hitung dan $t$ tabel maka dapat diambil kesimpulan bahwa secara parsial ada pengaruh yang positif dan signifikan antara disiplin kerja terhadap Prestasi Kerja. Dengan demikian Ho ditolak dan $\mathrm{H} 2$ diterima.

3. Dari hasil perbandingan terlihat $t$ hitung dan $t$ tabel maka dapat diambil kesimpulan bahwa secara parsial ada pengaruh yang positif dan signifikan antara motivasi Kerja terhadap Prestasi Kerja. Dengan demikian demikian Ho ditolak dan H2 diterima.

4. Dari hasil perbandingan terlihat $t$ hitung dan $t$ tabel maka dapat diambil kesimpulan bahwa secara parsial ada pengaruh yang positif dan signifikan antara kepuasan kerja terhadap Prestasi Kerja. Dengan demikian demikian Ho ditolak dan H2 diterima. 


\section{DAFTAR PUSTAKA}

[1] H. Sidanti, "Pengaruh lingkungan kerja, disiplin kerja dan motivasi kerja terhadap kinerja pegawai negeri sipil di sekretariat dprd kabupaten madiun," J. JIBEKA, vol. 9, p. 10, 2015.

[2] Hamali arif yusuf, Pemahaman Manajemen Sumber Daya Manusia : Strategi Mengelola Karyawan, Center for. Yogyakarta, 2016.

[3] Wibowo, Manajemen Kinerja, Ketiga. Jakarta: PT. Raja Grafindo Prasada., 2010.

[4] Siagian. P. Sondang., Manajemen Sumber Daya Manusia. Bandung: Bumi Aksara, 2012.

[5] Hasibuan MSP, Manajemen Sumber Daya Manusia. Jakarta: PT. Bumi Aksara, 2013.

[6] Citra Indah Zuana, "Pengaruh Pelatihan kerja dan lingkungan kerja terhadap prestasi kerja karyawan PT. Jamsostek (Persero) Kantor Cabang Malang," Univ. Brawijaya Malang, vol. (7) No 1, pp. 1-9, 2014.

[7] Aris Baharuddin, "Pengaruh Pelatihan, Kompensasi, dan Disiplin Kerja Terhadap Prestasi Kerja Karyawan PT.PLN (Persero)Area Pelayanan Dan Jaringan Malang," Univ. Brawijaya Malang, vol. (6) No.2, pp. 56-68, 2013.

[8] Sherli Astri Puspitaningrum, "Pengaruh Motivasi Kerja dan Disiplin Kerja Terhadap Prestasi Kerja Karyawan PT. Asuransi Jiwasraya Branch Office Malang," Univ. Brawijaya Malang, vol. (17), pp. 1-8, 2014.

[9] Henny Handayani, "Pengaruh Kepuasan Kerja Dan Semangat Kerja terhadap Prestasi Kerja Pada PT. Bumi Karsa Makassar,” Makassar, vol. (3) No.\$, pp. 8798, 2017.

[10] Sugiyono, Metode Penelitian Pendidikan (Pendekatan Kuantitaf, Kualitatif dan $R \& D$. Bandung: Alfabeta, 2014.

[11] Jundah Ayu Permatasari., "Pengaruh Disiplin Kerja dan Motivasi Kerja Terhadap Prestasi Kerja Karyawan PT.BPR Gunung Ringgit Malang.," Malang. Univ. Brawijaya Malang., 2015.

[12] Sylvia Indra Loana., "Pengaruh Motivasi Kerja dan Disiplin Kerja Terhadap Prestasi Kerja Karyawan PT.AXA Financial Indonesia Sales Office Malang. Malang.," Univ. Brawijaya Malang., 2014. 